\title{
Feminism in The Story of an Hour From the Perspective of Spatial
}

\section{Narrative}

\author{
WANG Xu \\ College of Foreign Languages, Zhoukou Normal University, Zhoukou, China, 466001
}

\begin{abstract}
The Story of an Hour is a short story written by Kate Chopin, an American realistic novelist, at the end of the 19th century. There are three spaces in the novel, the room, the house and space outside the window. Each one contains certain characters, actions, emotions and even ideology. This paper tries to analyze its Feministic significance of the novel from the perspective of space narration.
\end{abstract}

Keywords: The Story of an Hour, Spatial Narrative, Feminism

Classical narratology focuses on the study of stories and discourses in fiction at the time level. Until 1978, Chartman, first put forward the concepts of story space and discourse space. He pointed out that the latitude of story events is temporal, while the existence in story space, characters, and environment are spatial. Chatman's view inherits the traditional narrative theory that narration belongs to the art of time, but he puts forward the space latitude from the story level, and puts the almost marginalized space background of traditional novel into the theoretical research field as an existence. He believes that story space refers to the place or place where events occur. Discourse space is the place or environment where the narrative action takes place. Structuralist narrators generally believe that story space has important structural significance in narrative works. In addition to providing the necessary place for the characters to move, story space is also an important way to show the characters'psychological activities, shape the characters' images, and reveal the addresses of the works. In order to discuss these aspects, it is necessary to deal with the observation and description of story space. As far as the relationship between the perspective of characters and the space of stories is concerned, what is usually emphasized is the space in the eyes of characters. In this sense, we say that the space of narrative works is always filled with many meanings beyond the space. It can be said that the use of character perspective to show the story space can make objective environment space to show the observer's psychological activities, and the psychological space closely related to the ideological value. This technique helps novelists to shape the image of the characters and reveal the theme of the work at the same time.

In the 19th century, America was imprisoned by patriarchal ideology, so women were oppressed in all aspects of politics, economy, society, and psychology. Women's will and ideas were regarded as insignificant. Women should become "angels" or "virgins" in family, and sacrifice all their wishes and take husbands and children as the center of life. However, Kate Chopin, as a pioneer of American Feminism, deviated from the

WANG Xu, MA, Lecturer, College of Foreign Languages, Zhoukou Normal University, Zhoukou, China. 
patriarchal ideology and created some short stories which were considered unruly and immoral at that time. The Story of an Hour is one of her representative short novels. The physical space in the novel is not only an objective geographical location, but also a container carrying time, characters, actions, speech, psychological activities, values and ideology in it. The physical space, whether intentionally or accidentally observed by the character, reflects the character's judgment and choice more or less.

\section{The Relationship Between Focalization and Space in The Story of an Hour}

There is little description of the house, but we can see from the fragmentary introduction that the whole house has at least two floors. Mrs. Mallard has her own room upstairs, with a comfortable, wide rocking armchair near the window. She usually rests here, not only eliminating physical exhaustion, but also enjoying the relaxation into the depths of her heart. Through the window, she could see the vast square, the vibrant green trees, the free flying birds, the blue sky, and the white clouds; she could hear the salesmen, the chirping birds, and the distant songs; she could smell the sweet smell of the drizzle outside the window. The author does not directly introduce Mrs. Mallard's family background, but through Mrs. Mallard's perspective (vision, hearing, smell), indirectly reflects that Mrs. Mallard's life is superior, because the house is located in an excellent environment. She is the hostess of a middle-class family. In addition, the focalization must have the subjective thought and emotional projection of the observer. In the sad mood of the bereaved husband, why is she joyful and clear to observe the scenery, sound and smell presented by human vision, hearing, and smell? We know that the mood of the observer can affect the cognition of the objective things, that is, the objective things carry the inner world of the observers. However, the objective things in the novel are without the slightest melancholy atmosphere, but relaxed and joyful. Obviously, the inner world of the hostess still has hidden thoughts to be excavated. This kind of dramatic irony (the difference between what the reader thinks and the content of the text) will arouse the readers' curiosity and interest in reading.

The following psychological description of Mrs. Mallard in the room highlights her desire for freedom and self-identity. In this limited space, the focalization is extended to psychological perception, from outside to inside. The physical space of the room is as rich as the contents of the container. All of this is done through the focalization of the characters. The implied author hides outside the text, and there is almost no explanation of the writer. The description of the scenery outside the window in the former text has foreshadowed the heroine's different inner world and paved the way for the following text. At first, the heroine's yearning for freedom made her very frightened. She could not clearly define freedom. She felt freedom everywhere, in the sky, in the voice, in the scenery, in the color, even full of any corner of her life. When the desire for freedom began to emerge in her mind, she tried to suppress it, but in turn it became more and more intense. Until the heart emerged three words, "free, free, free", again and again to call her to grasp the chance of freedom, pulse accelerated, blood was boiling, and the whole body and mind had been greatly relaxed. She named this joy evil pleasure. There is also a dramatic irony below, that is, through the heroine's perspective, reflecting her husband's constant attention and love to her every day, but the heroine hardly loves her husband, or the number of love is very small. The latter part gives an explanation. It turned out that the Mr. Mallard's love was only out of selfishness, regardless of his wife's real thoughts. Mrs. Mallard wanted to find her identity and live for herself. She believed that it was a crime to impose one's will on others, whether the intension is cruel or good. The heroine's ideology finally really awakened, and 
she realized that what she wanted was self-affirmation and confidence. So when the voice of her sister begging to open the door appeared outside the room, no one knew that the protagnist was actually drinking the nectar of life through the window. Her thoughts were galloping. In the years to come, no matter summer, autumn, or winter, any time belongs to her. She sighed how long her life had been without her identity before, and then she prayed that the days of freedom would be longer.

\section{The Relationship Between Theme and Space in The Story of an Hour}

The core space of the novel is the upstair bedroom which symbolizes the protagnist's psychological space. The author does not narrates much about this physical place, only a comfortable and spacious rocking chair and an open window. We can vaguely see that the protagnist's living conditions are superior, but in this private space only one window opens to the outside world, where there are blue sky, white clouds, fresh air after rain, distant songs, and countless sparrows, showing the vitality of a new life in spring. The whole house represents a patriarchal family, and her husband watched her with loving eyes all the time. The husband's so-called loving gaze is only a manifestation of love for himself, or just a male gaze, that is to say, satisfying the partner's appearance or character conforms to the social and cultural norms. She is young, white, serene, obedient, weak, and has heart trouble, who needs to be protected by others. In the family, she is just like a comfortable rocking chair. It is only an object or a materialized existence. Her husband has never realized the wishes and expectations of his wife. Therefore, such feelings are selfish and oppressive "love" of women. Putting women on the high shelf, like the Virgin Mary, is actually the worship and maintenance of the image of female "family angel" under the patriarchal norms, fundamentally in order to safeguard the rights and interests of men. It was not surprising that she admitted that she had loved him, not often, sometimes. Although the protagnist has been waiting for freedom and longing for freedom, she has never lived for herself. The centre of her life is her husband. The oppression and fatigue under the patriarchal will are surrounded in life and make women breathless all the time.

It is impossible for her relatives and friends to understand her real state and needs including her sister and her friend Rechards. She did not allow anyone else to enter the room, suggesting that she was estranged from the surrounding society, that the outside world did not understand her, and that she did not allow others to enter her inner world. Her sister told her husband's death half-covertly in intermittent words to prevent her from having a heart attack. In their minds, the heroine was a weak traditional woman. When her husband died, she would lose the support of her life. Most women would feel sad and be at a loss. She cried bitterly in her sister's arms at the very beginning. However later, her sister begged outside the door trying to persuade her not to do silly things. Richard tried to hide her husband when he came home, so as not to stimulate a series of heart trouble, which strengthens the vulnerable image of women in ordinary people's minds.

Although the protagnist's longing for freedom lasted for a long time in her heart, she was at a loss. From the beginning, she felt abandoned and sobbed. Finally, she saw the scenery outside the window. Her voice for freedom grew louder and more frequent. She was frightened at first and did not know what this thing was. Later, she tried to suppress the idea, wondered if it was evil, and finally felt relaxed and warm in body and mind. At sister's repeated requests, she opened the door and came downstairs like the goddess of victory. She grabbed sister's wrist as if it was someone else, not herself, who was injured. However, before she could stand firm, her husband came back. It was too late. She died of despair or the destruction of a new life, rather than the sudden joy 
that everyone thought. We can see that for the lady, the space of the room carries all her fantasies and hopes, and in fact symbolizes her psychological space. In her short stream of consciousness, which lasted only an hour, all happiness suddenly came and all went away in a hurry. Do not mention the society represented by going out of the window. She had just come downstairs, but she had not yet stood firm. All the fantasies have been shattered. In that patriarchal society and soul, hope can only exist in imagination, limited by space (the room) and time (only an hour). We cannot help thinking that even if the woman has no heart disease, when her husband came back, her heart would also turn to dust. Even if it was not subject to the ideological imprisonment of husbands, the society in which they lived would always permeate the ideology of oppression of women.

\section{Conclusion}

In short, the novel revolves around Mrs. Mallard's psychological reaction after she learned that her husband had "died" in an accident. In her stream of consciousness, the novel reveals that patriarchal ideology in 19th century American society is pervasive everywhere and everytime. The three physical spaces in the article: the house, the upstair bedroom, the square and the sky outside the window, respectively symbolize the patriarchal family, women and society. Room represents men's respect and praise for women and their high admiration. In fact, the patriarchal society represses, regulates, and restricts women. Women have no freedom both of body and mind, without personal will. Men love angels and virgin who abide by social rules, not women who exist as natural persons. Room represents women's private psychological space from another aspect, which is enclosed narrow, full of fantasy, unrealistic, and once out of fantasy, will fall into despair and even spiritual death. Women themselves are also seriously persecuted and influenced by patriarchal ideology. They are ideologically internalized, doubtful, and self-confident. Room also indicates that women are incompatible with the surrounding social environment. Women prevent society from entering their hearts, and the social environment cannot understand women. People take it for granted that women should be weak and helpless and need to be protected. In fact, they depreciate the value of women's existence and strengthen the way of thinking attached to men. Paradoxically, room is a part of the house. Room has its own special emotional, psychological and even ideological meaning. It is unreal to exist independently of the house, because women were oppressed and confined in that time of patriarchal society. Women could have new ideas and the will of persuing freedom and individuality, but it was ardious for them to seperate from the bondage of time and space. That is why the title of the novel first published in 1894 is The Dream of an Hour, which just show the protagnist's an hour's dream. The author also deeply regrets that women's independence and equality in the society at that time was mirage, like a castle in the air, nihility, fleeting.

\section{References}

Luo, T. (1994). The dilemma and self-help of modern American women. Study of Foreign Literature, 158-162.

Shen, D. (2015). Western narratology: Classics and post-classics. Beijing: Peking University Press.

Tyso, L. (2014). Practical guide to contemporary critical theory. (G. X. Zhao et al., Trans.). Beijing: Foreign Language Teaching and Research Press.

Wang, Q. (2008). Study of irony and symbolic art in Tempest. Appreciation of Famous Works, 103-106.

Zhu, H. (1983). Short stories by American female writers. Beijing: China Social Sciences Press. 